\title{
"Towards a Renewable Urban Sustainability" Decoding the Egyptian DNA of High Performance City
}

\author{
Gasser Gamil Abdel-Azim, Baher Is mail Farahat*
}

Architectural Department, Faculty of Engineering, Egypt, (Misr International University-MIU), P.O.Boxl, Heliopolis, Cairo

\begin{abstract}
This paper proposes and discusses one of the January2011 Egyptian revolution priorities. The dream of every citizen, to shift the Egyptian cities from having a conventional consumer ignoring our resources and multiple potentials into having a productive country, that makes the best out of its environment and capacities. In this paper, potentials include liquid and solid waste as well as energy and building materials. Furthermore, the research problem can then be stated in the absence of visions, strategies and mechanisms that would be devised to upgrade or develop the performance of any urban settlement. Based on previous studies, some elements like Transportation, Energy, Water, Waste, Microclimate and Materials were proven to be key aspects and convenient to our Egyptian cities. There are several local and international studies on the issue have tackled one or more of the elements, however missed out on the rest, or have not drawn up a comprehensive strategy for integrating them all together. Hence, no study was found to have tackled them in a comprehensive methodical manner with an aim of upgrading or development pertains to the urbanism process. Several literatures is witnessed to deal with these six bases on different levels, either on a single building level, a group of buildings, or a neighbourhood. However, it was never for a city, except for some trials such as Masdar city located in Abu Dhabi which has deployed some of these elements. In this classic "Image of the city", Kevin lynch has proposed such elements as descriptive tools. Afterwards, no further studies have worked on their assessment, as true valid determinations of the city's urbanization process. Thus, the purpose of this paper is to exp lore what can be described as the DNA of High Performance City. It is in an attempt to reveal the characteristics of their bases and clarify the reciprocal of the relationship between the key cycles and a cleaner-better discipline of our cities, which uses whole-built environment design to achieve energy, economic and environmental performance which is substantially better than standard practice. High Performance City (HPC) planning is a chance to use our resources efficiently while creating healthier build ings that would improve human health, build a better environ ment, and provide cost savings.
\end{abstract}

Keywords Sustainable Development, Conventional City, DNA of High Performance City, Six Bases of HPC

\section{Introduction}

The field of sustainable development can be conceptually broken into three constituent parts: environmental sustainability, economic sustainability and socio-political sustainability. These three parts should be efficiently achieved if we want to reach to High Performance Cities.

The concept of sustainable development, with emphasis on the environmental compassion, has presented a challenge to the developing cities. It has an essentially relative and normative character. Based on the definition, the important concepts of implementing sustainable development is firstly the re-use of build ings and lands required for development within the existing built-up areas, thereby reducing or preventing urban sprawl, secondly it protects and enhances

* Corresponding author:

baher.ismail@miuegypt.edu.eg (Baher Ismail Farahat)

Published online at http://journal.sapub.org/arch

Copyright (C) 2012 Scientific \& Academic Publishing. All Rights Reserved the character of built environ ment communities, the identity of towns and district centres, manage the use of natural resources to avoid depletion and permanent damage, maintain and enhance the cities ecosystem,[17].

\subsection{What is a High Perfor mance City (HPC)?}

HPC is where we explore and make use of all the inputs and outputs available in a city whether these energies were positive or negative. We will make the maximum efforts in order to convert the negativity of a conventional city into a prudent city which makes the maximum benefits and best results out of the various available possibilities including economics, climate, and environmental.

Additionally, the concept of HPC has been implemented in many countries worldwide; however it has never implemented in our country till this point regardless the huge number of potentials and energies we have got.

The concept was only considered and put into thought after the Egyptian revolution. Moreover, Councilman Blum quoted "I feel the city need strong leaders, and we need to let 
the citizens have confidence in skilled and knowledgeable", speaking about HPC.

Generally, there is no specific model which determines the strategy of implementing the concept of HPC as it varies due to each country's potentials and energies. According to several different studies regarding the strategy, it was found that some studies depended on some elements like green building incentives, updating building codes, Operations and Purchasing, Financing Strategies, Renewable Energy Development, Transportation...etc, while other studies depended on other different elements like city planning process, site design and planning process, construction management of the city, materials and product selection, indoor environment- water management, operations and maintenance of the city...etc. , Figure 1.

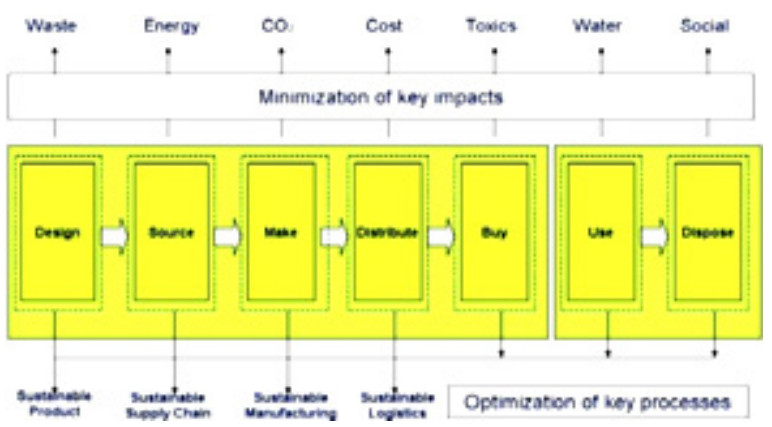

Figure 1. Resources implemented in Masdar city- Abu Dhabi

All while other studies in other cities suggest that those elements of HPC are transportation: resizing and greening city fleets, incentives for efficient car-use, smart growth policy, improving mass transit, upgrading traffic signals and street lights...etc, financing strategies :bonding initiatives, revolving funds, pension fund investments, energy savings performance contracts, point-of-Sale energy-efficiency upgrades...etc. But, this research focused on explain ing the elements, potentials and energies only that is easy to use and implement in the Egyptian cities.

\subsection{Why are High Perfor mance Cities nee ded in Ge neral?}

The causes of reaching to High performance cities are reaching to an improved services and reduce costs leverage talent, technology, training, tools imagination, investment, innovation, learning continuous quality improvement "by sharing, we all gain", large and small manufacturing, service and non- profit, common denominators strong interest in cost-effective training desire to learn from experience of others willingness to share, emphasis to efficient use of energy, water, materials and focusing on minimizing environmental degradation that is associated with buildings and infrastructure. The design of High Performance Cities also emphasizes on the relationship between the building occupants and workspace, in order to create an indoor environment that is safe, comfortable and foster productive. The mechanism of High Performance Cities use energy, water, and other resources more efficiently while reducing the overall impact to the environment, generally HPC give share vision for a change[18].

\section{The Philosophy behind High Performance Cities}

The vision for high performance city should execute the needs and aspirations of its residents. It should be a place where individual towns and communities can thrive, has a high quality environment which is safe, secure, and protected from pollution. The physical resources are sustained and not compromised. Moreover, the access to goods and services is provided in a manner which minimizes the need to travel and the impact of transportation on the environment. This vision is achieved through three points:

Firstly, environmental impacts and resource utilization are of primary importance in the design and construction process of high performance cities. The entire life cycle of the built environment and its ingredient components are carefully considered. For materials, architects and other design professionals consider the entire life of the product from resource extracting and use in the built environment to the disposal process at the end of its useful life.

Secondly, emphasis on renewable resources for energy systems; recycling and reusing of water and materials, integration of native and adapted species for landscaping; passive heating, cooling, ventilation and a wide range of other approaches that minimize environmental impacts and resource utilization.

Thirdly, make an economic sense, not always on the capital or first cost basis, but virtually always on a life cycle basis. Rainwater harvesting systems that collect and store rainwater for non-potable purpose are an additional new system that cost extra money due to the need for additional piping, pumps, controls, storage tanks and filtration components, [8].

Therefore the use of High performance cities meet the challenges of achieving a health community and provide several layers of consistent approaches that promotes inhabitant health. A successful concept of high performance city has some main principles:

- Sustainability, natural recourses are limited. Hence, sustainable principles need to be incorporated within the plan.

- Flexibility, policies and strategies need to adapt to the dynamic nature of the planning and changes in people demand.

- Partnership- all stakeholders are required to participate in the way which the land is utilized, to assist in developing policies and strategies and to work towards common visions.

\section{The DNA of the Egyptian HPC: Transportation, Energy, Water, Waste, Micro Climate and Materials}


The definition of DNA is "Deoxyribonucleic Acid" or "Did Not Attend" or"Does Not Apply". It is now possible for scientists to identify not just the genes, but the individual bases. Before the discovery of DNA, scientists could only uncover the evolutionary tree of life by comparing the bodies and cells of different species. Now they can compare their genetic codes and work their way down to the deepest branches of life dating back billions of years. Therefore, the study of the DNA; was a reaction to the urge of developing hereditary genes of man as means to understand the behaviour of the body, and later on to increase the performance of the systems and organs from one generation to the next,[23].

\subsection{Why is the DNA Physiology used?}

The concept and mechanism of the DNA was explained and related to in this research because of the natural way which relates the DNA genes and formulation of each human being with their behaviours in the society and their way of living. Similarly, the genes of the HPC is responsible and in control with establishing these cities and increasing its competencies, or can be the reason for its evanescence.

The manipulation in the genes of the DNA with an increase decrease, percentage or a specific quantity causes a huge change in the live efficiency of the functions. Likewise, the handling and control in the genes of the HPC for any country with an increase, decrease, carful using or misusing the elements and their interactivity between each other showed a significant change in the competencies of these cities. The functional mechanis $m$ of the HPC elements was devised from the mechanism of the DNA of any living organism.

From a similar perspective, the idea of developing a philosophy for the study's and analysis of the cities' DNA was created. The tool is envisioned as a mean to assess the urbanization determinations of the city, and thus changes, develop or activate any or all of them: developing endless cycles and infinite possibilities of interactions between the elements or urban "genes".

Based on the fact that cities are variable accordingly with the human's body, thus the proposed urban genes will vary in priority and activity upon experimentation. It will be helpful then to elect the elements that need reinforcement. Based on the preceding, the aim of this paper is to propose a tool through which city genes can be upgraded and developed towards their ultimate urban performance.

DNA is a nucleic acid present in the cells of all living organisms. It is often referred to as the "building blocks of life," since DNA contains the genetic instructions used in the development and functioning of all known living organisms. The information in DNA is stored as a code which is made up of four chemical bases: adenine (A), guanine $(\mathrm{G})$, cytosine $(\mathrm{C})$, and thymine $(\mathrm{T})$. A ll the bio logical instructions of a human being can be written with these four letters. The order, or sequence, of these four bases determines the information available for building and maintaining an organism. The DNA segments that carry this genetic information are called genes. A gene is normally a stretch of DNA that holds the information to build and maintain an organism's cells and pass genetic traits to offspring. Such as eye color or nu mber of limbs[19], Figure 2.

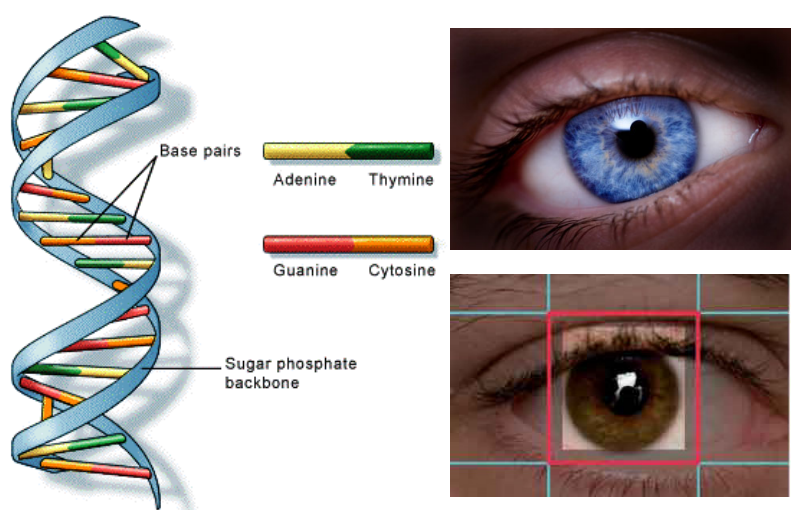

Figure 2. The DNA bases, many genes hasmany different biologicaltraits

Decoding the DNA of organis ms and discovering the rules that govern its systems enable researchers successfully to enhance the conservation of many animals and plants on the earth using genetic engineering technologies. Building on this success, the paper poses the question: why not in urban sustainability? Therefore, the paper adopts the hypothes is that conserving the DNA of High Performance City will ensure its sustainability.

Upon upgrading of urban settlements and cities, several trials were conducted by professionals to discover the certain elements that would help successful upgrading and development. They reached at some elements sought as the key bases for the efficiency of any physical setting.

Generally those bases of the DNA in the Egyptian cities are summarized in six bases: Transportation, Energy, Water, Waste, Micro climate and Materials. These bases need to coexist in a meaningful way in order for an experience of HPC to occur.

However, "HPC" itself, is not a theory, it is the starting point from which all the designs for built environments should begin, and the start point for urban sustainability to be achieved. There are tangible phenomena such as rocks, water, trees, sun, moon, stars, animals and houses - and there are intangible phenomena such as our feelings. Everything else; atoms, molecules and data, are abstractions - they are tools that serve other purposes.

The idea behind decoding the DNA of HPC comes to explore the meaning and values that constitutes those environments and generate its building codes in order to be able to reproduce these environments again, Figure 3.

In the following sub-sections, the paper will try to shed light on the meaning of the DNA of High Performance City through the study of the previously determined bases of this DNA, which are Transportation, Energy, Water, Waste, Microclimate and Materials. However, one must consider how it works, how it accommodates, how it fits, and what it affects. When speaking about High Performance City, a site 
is the particular circumstance, or situation within where a building will be located. It involves the non-visual and invisible build ing codes and vocabularies that would make us able to reproduce these environments again.

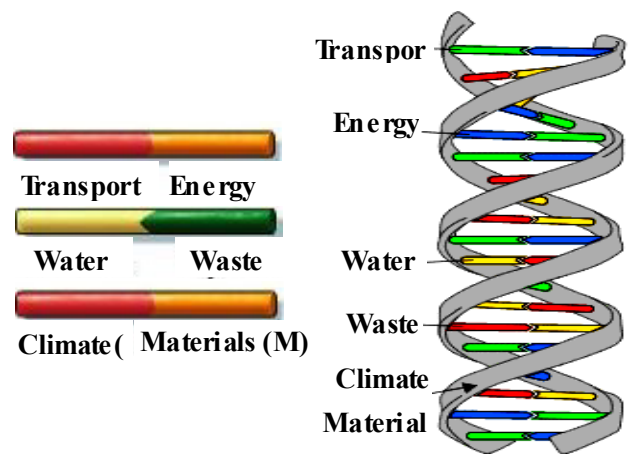

Figure 3. The DNA of six bases which hopefully repair the Egyptian cities

\section{Decoding the Egyptian DNA of High Performance City Key Cycles}

An Egyptian city's metabolis $m$ is comprised of six cycles where each has their own individual patterns but in some way all influence one another: transportation, energy, water, waste, micro climate, materials. Naturally many of the decisions to be made with respect to the above, are site specific and would necessarily take into account basic factors such as: the climate (solar, temperature, humid ity, precipitation, wind) geology (site conditions, materials resources, topology), location and economics of the country...etc. Ho wever, in many cases the generalobjectives remain the same. The key cycles of high performance Egyptian cities are;[3] Figure 4.

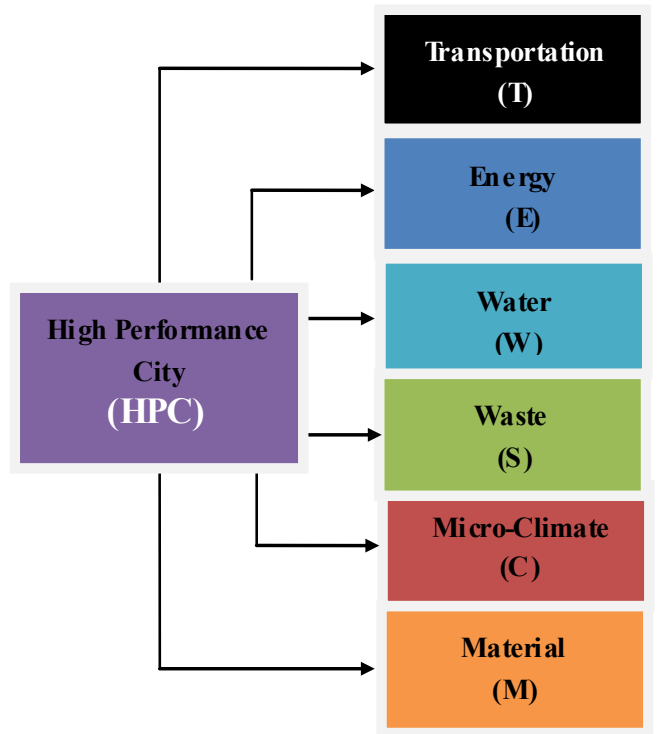

Figure 4. The key cycles of High Performance $\mathbf{C}$ ity

\subsection{Efficient Trans portation}

"Creating sustainable transport systems that convene a person that needs justifiably and foster a healthy environment requires putting the automobile back into its us efulplace as a servant. With a shift in priorities, cars can be a part of a broad, balanced system in which public transport, cycling and walking are all viable options"[18] Therefore, the challenges are to avert this predictable disaster from actually occurring without denying citizens of the developing world that has indisputable benefits which increases personal mobility which is facilitated by the benefits a car can bring. The key to a sustainable transportation system is the completion of a transport hierarchy which gives priority to pedestrian and public systems above the car[3].

This does not necessarily imply positive discrimination against the private car. Ho wever, success ful implementation of such a hierarchy can be achieved by only creating an environment which is not provided for the car. This can be accomplished by limited parking spaces, traffic calming, cheap mass transit and by establishing a network of roads which is unsuitable for vehicular traffic, pedestrian, cycle based, mass transit (public), and car. The hierarchy chosen will say which modes have design priority over others. Successful implementation of such a structure will depend upon a segregated environment and will fundamentally effect design decision. In order to encourage people to use public network, walk or cycle is important where the system must be of a high quality and provide similar or better service, Figure 5.

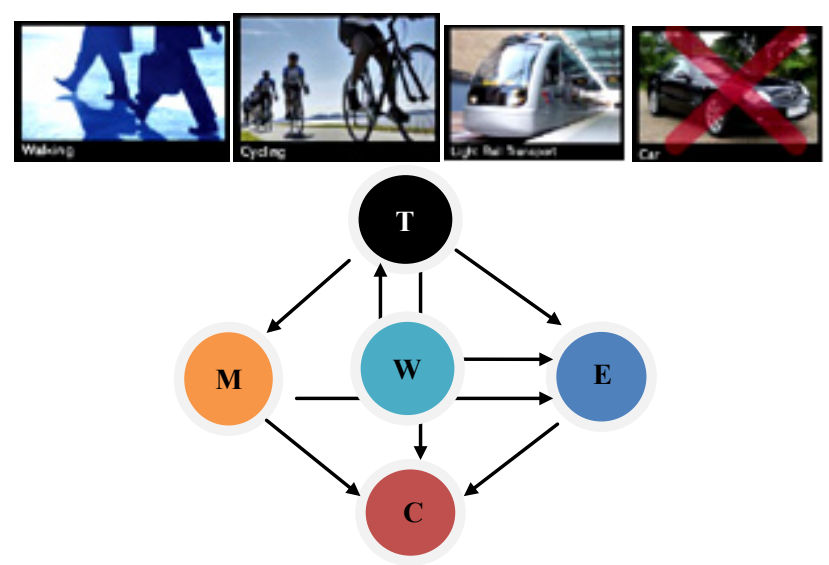

Figure 5. Transportation strategy- Non Carbon system

\subsection{Efficient Energy System}

The fundamental princip le of any energy strategy must be to reduce the demand and to supply the energy required from a renewable source thus creating a self sustaining. Building demand can be limited by producing design guidelines and energy targets for given plots of land. Typically, this will pressure decision making with respect to both the building systems and architectural response. Prominently, it willp lace greater emphasis on the architect to develop a building type that is environmentally responsive rather than being environmentally rejected. Thus, buildings need to be naturally ventilated whenever is possible, by day lighting, limiting the use of air conditioners, utilize solar energy for heating, cooling and ventilation efficient systems, careful orientation, planning and suitable materials choice. 
Renewable sources include: bio mass, solar energy and wind. Computer modelling is an extremely useful tool in optimizing design of electrical and mechanical systems and the building shell.

There are wide ranges of action necessary to change the city which is agitated and powered from the traditional centralized grid model run from large power plants. In order to achieve this scale of change in the shortest time possible, a wide range of policies, strategies and mechanisms need to be applied to the challenge. This includes Changing legislation and standards, Provision of incentives and disincentives, Institutional reform and imp roved strategic, general planning practices, Community action development, industry alliances, information and education and Re-educational program for related professionals,[8] Figure6.

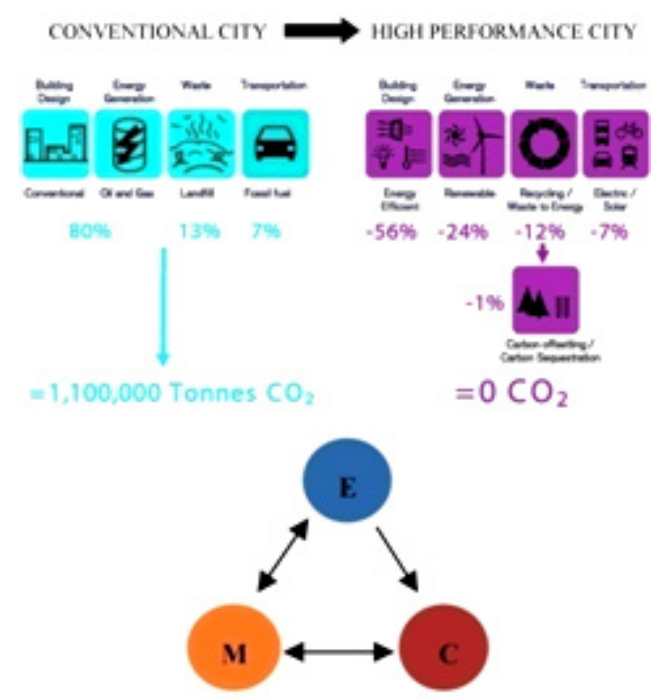

Figure 6. Energy Strategy - $100 \%$ Renewable

\subsection{Water Efficiency}

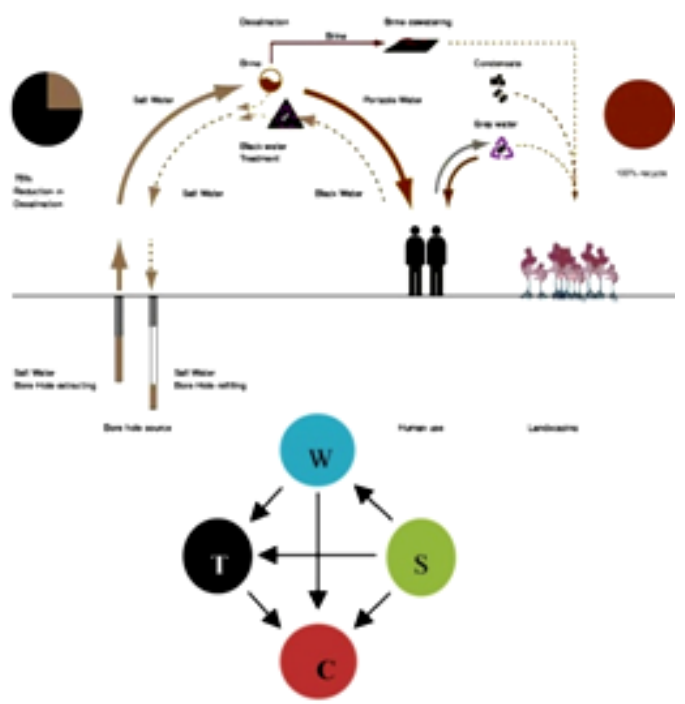

Figure 7. Water strategy $-100 \%$ recycles

In most cities including Egypt water is a valuable and scarce resource. The achievement of a self- sufficient system, demand reduction, collecting and storing water over days or months to ensure that it is available all year round, treat and distribute water to areas of need efficiently, recycle waste water where possible for use in WCs or landscape. In many areas of the world, The city should be designed around the need to collect and store water in underground areas, tanks from central squares and act as a significant thermal heat sink- creating a cool micro climate within their immediate vicinity, whilst the above ground water surface (lakes and canals ) not only provide $\mathrm{v}$ isual a menity but also a degree of evaporative cooling. In addition, the canals from primary routes along with the landscape can be integrated to form pedestrian walkways and wild life corridors,[1] Figure 7.

\subsection{Efficient Waste Management}

Generally, Waste can be broadly categorized into four forms: human effluent, bio-degradable / explosive waste (paper, vegetable materials), non-combustible waste (metals, glass etc), and toxic waste. It is essential that waste strategy carefully deal with these categories and that waste is not necessarily seen as something to be disposed of, but as a resource to be re-cycled and re-used, human effluent produces gas for heating/ cooling power, mud for composting and water for landscaping. Biodegradable/ combustible waste can be cleanly combusted to provide power and heat, provide compost and ash, and can be used for road construction/ collective. Non-combustible metals (metals, concrete, and glass) can be recycled or sold on to other areas. Toxic waste must be reprocessed by specialist offsite plant,[1] Figure 8.

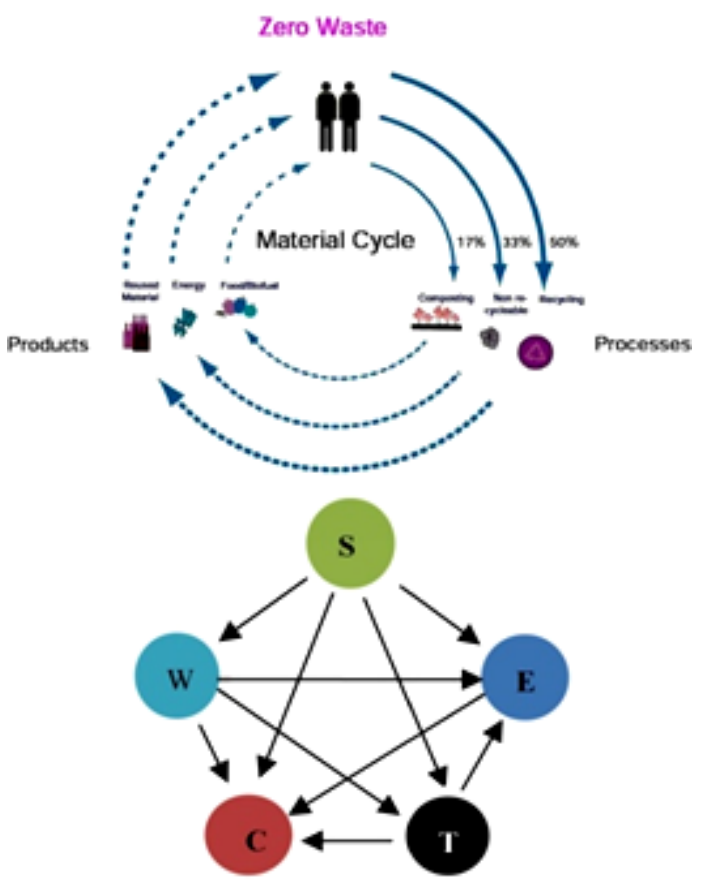

Figure 8. Waste strategy- Zero waste lifestyle

\subsection{The Creation of a Comfortable Urban micro-climate}

The creation of a comfortable urban micro-climate is necessary to the successful operation of urban transportation strategy of the sustainable city. This will basically affect the 
planning and layout of the urban environment. The climatic elements within the urban area that can be customized by a sensitive urban design include: air temperature and humilities, radiant temperature to which occupants are exposed wind speeds in streets and round buildings, concentration of air pollution within traffic arteries, potential for natural ventilation, shading, daylight, solar exposure and solar energy utilization. The urban factors that the urban designers have to control over and that will affect these aspects are topographical features of the city, density and color of buildings, distances between it, orientation and width of street urban parks, landscape, and material-choice [24].

The aim of adapting such an approach is not to create a changing thermal, air quality, acoustic nor a light topography that recognizes the need for varying landscapes. Thus streets may have a combination of fixed and variable shading systems. Bus stops and public squares may have a concentration of evaporative cooling systems (in typical northern climate of our city) or permit good solar penetration. landscaping and green areas will play a vital role in the creation of the urban-cape and have a marked influence on urban environment through allowing fauna, flora, wild life a natural path into and through the city, protecting them from hot or cold winds, provide evaporative cooling, absorption of solar radiation, reduction in natural dust and air pollution particles, rainwater absorption, impede or redirect wind to improve natural ventilation of building or surrounding areas,[26] figure 9 .

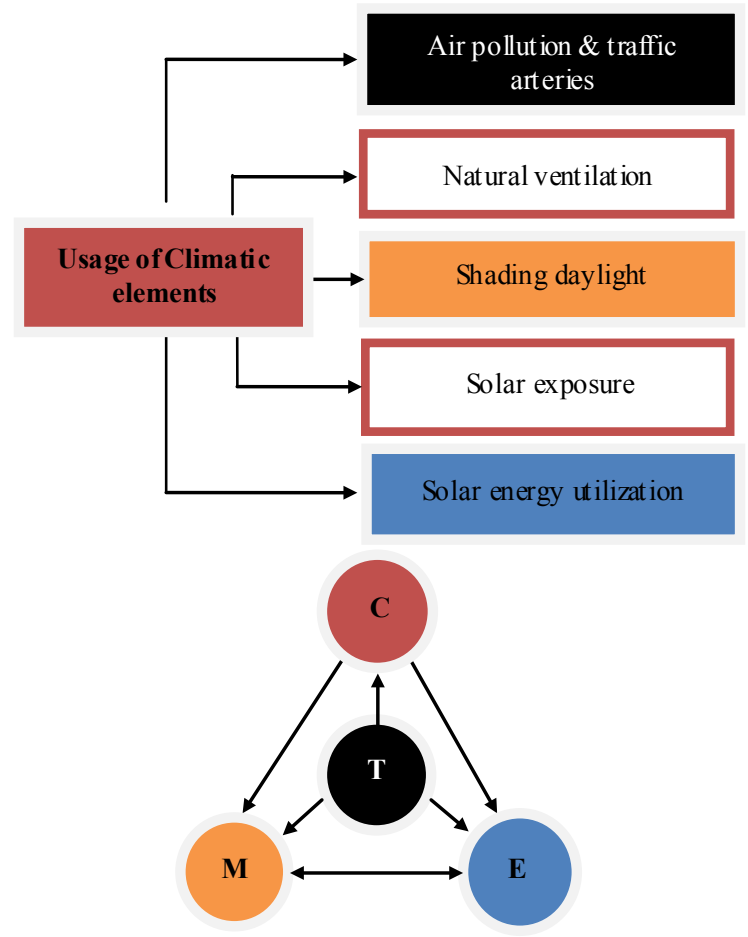

Figure 9. The creation of urban micro-climate

\subsection{Green Buil ding Materials}

The choice of construction materials will play an important role in the sustainability of a high performance city. The materials should be suitable for the climatic response required of our city, low embodied energy, utilize local skills for construction, suitable for the chosen structural government.

Green building materials are collected from renewable, rather than non renewable resource and environmentally responsible because impacts are considered over the life of the product[25].

Depending upon project-specific goals, an assessment of green materials may involve an evaluation of the following criteria resource competence, indoor air quality, energy efficiency, water conservation and affordability. Product selection can begin after the establishment of project-specific environmental goals. The environ mental as sessment process for build ing products involves three basic steps research, evaluation and selection:

Research: Identify the full range of the project's building material options. This step involves gathering all technical information to be evaluated, including manufacturer's information, other environmental issues, building codes, government regulations, build ing industry articles, model green building product specifications, and other sources of product data. Eval uation: A life cycle assessment (LCA) is an evaluation of relative greenness of building materials and products. LCA addresses the impact of a product through all of its stages. This approach has been difficult and expensive in actual practice. Selection: The total score of each product evaluation will indicate the product with the highest environmental attributes. The use of green building materials and products represents one important strategy in the design of a build ing,[24].

\section{Design a Strategy for Egyptian High Performance Cities}

This design process will involve highlighting the areas of both positive and negative interaction which is leading to an emphasis on certain areas, which will inform the urban an architectural design.

As mentioned previously, the genes were chosen carefully to represent and focus on the heart of the Egyptian cities, whereas those genes may differ in any other country. The genes represented are; transportation, energy, materials, micro climate, water and waste. Therefore, how can the competence of the Egyptian cities increase from the interactions of the mentioned genes? That could be achieved by several examples as following (the gene mentioned at the starting point of the arrow will be leading to the gene stated at the end of the arrow head):

\subsection{Tr ans por tation and Water}

Raising and enhancing the interaction between the genes of transportation and water by using the marine transportation stops alongside of the Nile River from Ale xandria to Aswan. $(\mathbf{T}) \longleftarrow(\mathbf{W})$, Figure 10. 


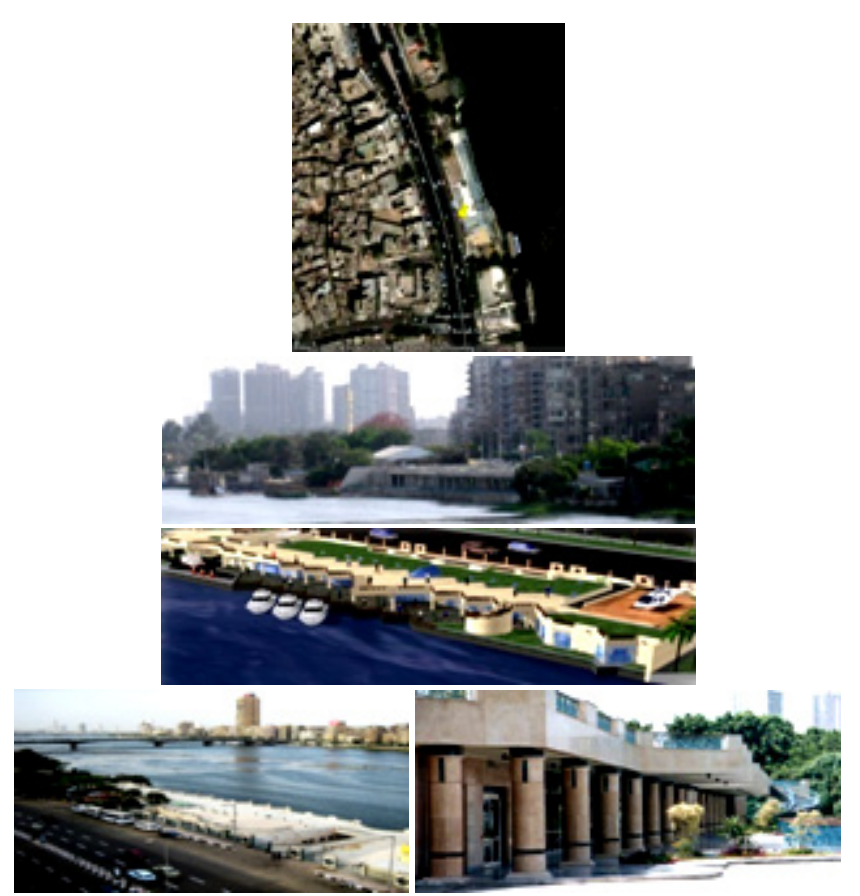

Figure 10. live shots of the marine transportation stops

\section{2 . Energy and Waste}

Increasing the interaction between the genes of waste and energy. This will be achieved by using the various kinds of wastes that takes a huge spaces and available endlessly in the Egyptian cities and recycle it to be converted into energy, (E) (S).

\subsection{Waste and Materials}

This will be achieved by using the various kinds of wastes that is available widely and process it into a useable kinds of materials, $(\mathbf{M}) \longleftarrow(\mathbf{S})$, Figure 11.
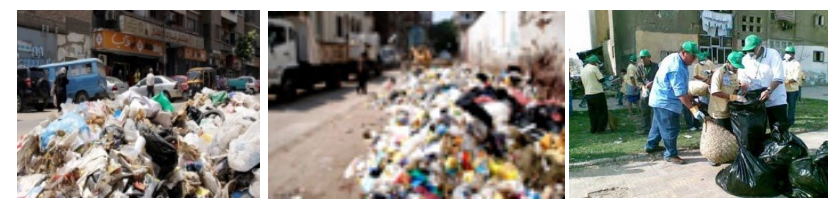

Figure 11. wastes disposed and its classification process

\subsection{Energy and Climate}

Egypt is known for its hot and sunny weather, and so we can use the interaction between the genes of climate and energy by converting the heat of the sun rays into solar energy using special panels, $(\mathbf{E}) \longleftarrow(\mathbf{C})$.

\subsection{Water and Waste}

Increase the interaction between the genes of water and waste. This will be by using all the water waste output as fertilizers to the soil, and as a result we can enhance the external look of the city by various kinds of plantation, $(\mathbf{W}) \longleftarrow$ (S).

The morale of the strategy states that there are endless kinds of interactions besides the ones mentioned above that can be used wisely for the betterment of Egyptian cities, and if all the interactions between all the different genes which are responsible for the competencies of any Egyptian city took place, it will form the DNA model, which emphas is on the connectivity and the relationship between the different six genes mentioned and can be easily interpret by the planner, designer or the government of the city, Figure 12.

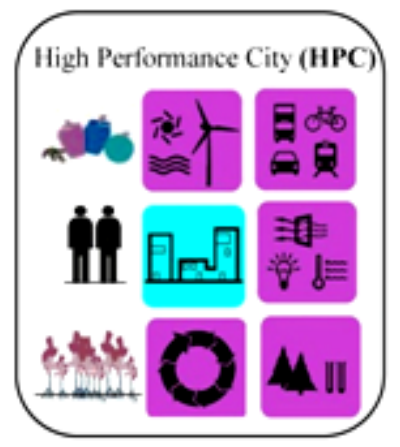

$$
\text { The Backbone of the city }
$$

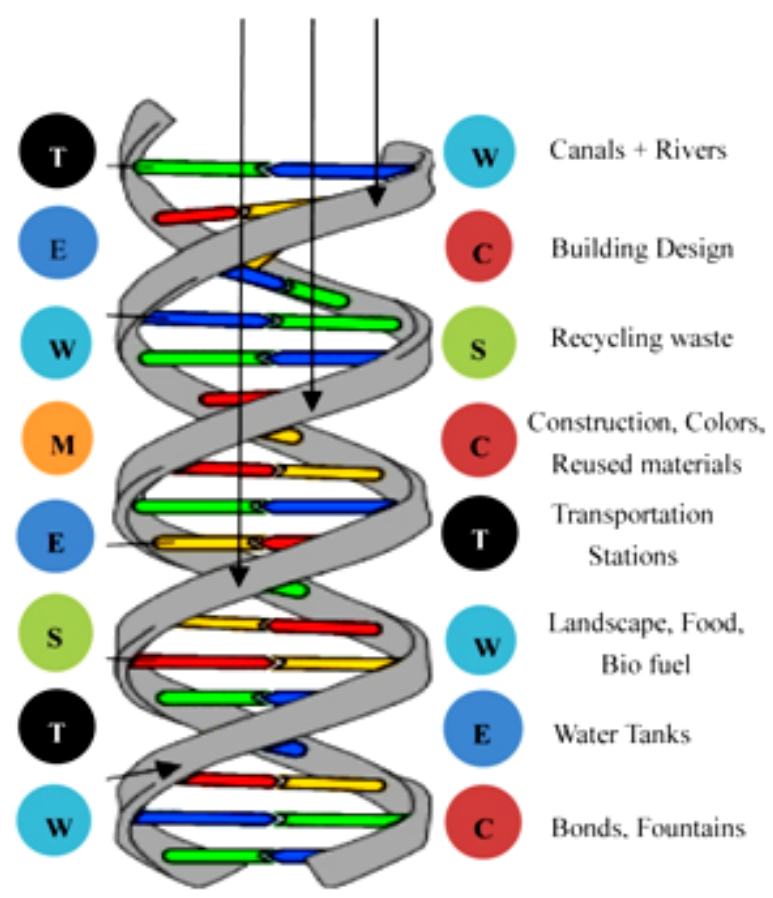

Figure 12. "Only one output from the key cycle Inputs to another" Reciprocal relationship between the key cycles to achieve cleaner-better Egyptian cities

The very nature of this approach means that firstly, each of these cycles should be analys ed separately of each other and the urban plan in order to idealize their operation. It is then possible to create a profound tool which is made up of all the individual components including the urban objectives. They can then be moulded together to create a working metabolis $m$ through the explored mechanis $\mathrm{m}$.

\section{Concluding Remarks}

Success ful High Performance City can be achieved if we consider the following steps: Establish a vision that 
embraces sustainable principles and an integrated design approach, Develop a clear statement of the project's vision, goals, design criteria, and priorities, Develop a project budget that covers sustainable built environment measures. Moreover, allocate contingencies for additional research and analysis of specific options and seek advice of a design professional with sustainable built environ ment experience.

If we do succeed in developing a Strategy for a High Performance City, it is likely that it will have the following characteristics: All processing materials will be designed to be cyclical. There will be no such thing as waste or pollution, except for outputs from one system inputs or another. The driving physical energy used by society will be renewable solar energy, rather directly or in forms such as wind, hydropower, and bio mass,[14].

This paper has argued on the new method which should approach the planning and design of Egyptian High Performance Cities. Business-as-usual is not the only path open to us. Hu manity could have a bright future if the entire world:

- Made use currently confirmed technologies and techniques. The same technology that has been emp loyed to restrain and conquer nature needs to be employed for the benefits of nature, and in turn for the long-term benefit of the human,[14].

- Greatly improve the efficiency of our resource use, and to significantly reduce our waste-stream going into the environment.

- Maintain and conserve renewable resource systems, like topsoil, fisheries, forest, and water supplies.

- Stabilized overall consumption of resource through switching, especially in industrialized countries, to a focus on "better and enough" (quality) rather than "more" (quantity).

- Efficient distribution of responsibilities between government levels

- With this analysis of the bases of DNA of Egyptian High Performance Cities (Transportation, Energy, Water, Waste, Microclimate and Materials), one could interpret the lack of sense of the city in today architecture and urban sustainability. The new and changing world of science and technology has left us with the inability to distinguish where one city ends and another begins.

- This is why the urban sustainability becomes a vital is sue in today's architecture and urban design processes. What is needed is an architecture that fully understands its genetic order, its genome system, bases and recognizing its primary purpose for human experience.

In this manner, the urban planner, the architect and the engineers can work together with the various specialists to create an integrated plan and strategy based upon informed decision making. This approach to urban design is, however, more involved and more complex than the traditional methodologies for it which involves examining the problem that is not only two or three dimensions, but in seven or eight dimensions.

\section{REFERENCES}

[1] Battle, Guy \& McCarthy, Christopher, (1994). "MULTI-SOURCE SYNTHESIS THE DESIGN OF SUSTAINABLE NEW TOWNS", Architectural design Magazine, London.

[2] Brand, Glen, (2010), "GREEN BUILDINGS FOR COOL CITIES".

[3] Brundtland, R. (1997), "WORLD COMMISSION IN ENVIRONMENT \& DEVELOPMENT OUR COMMON FUTURE". Oxford: Oxford University Press.

[4] City of New York. The Department of Design and Construction, (1999), "HIGH PERFORMANCE BUILDING GUIDELINES PROJECT", New York City.

[5] Davies J. et al. (Eds.), (1994). "SUSTAINABLE URBAN PROJECTS: PRINCIPLES OF IMPLEMENTATION". Torino, Italy: European Academy for the Urban Environment.

[6] ECE, Economic Commission for Europe (1996). "GUIDELINES ON SUST AINABLE HUMAN".

[7] Energy Information Administration, (2008). "ASSUMPTIONS TO THE ANNUAL ENERGY OUTLOOK". USA.

[8] Gorden, Kate and Ode, Susan. "HIGH PERFORMANCE CITIES A GUIDE TO ENERGY- SAVING POLICIES FOR URBAN AREAS", ICLEI Local Governments for Sustainability.

[9] GSA Public Buildings Service. (2008). "ASSESSING GREEN BUILDING PERFORMANCE: A POST OCCUPANCY EVALUATION OF 12 GSA BUILDING", USA.

[10] Langdon. Davis, (2007). "THE COST OF GREEN REVISITED: RE-EXAMINING THE FEASIBILITY AND COST IMPACT OF SUSTAINABLE DESIGN IN THE LIGHT OF INCREASED MARKET ADOPTION". USA.

[11] Lewis, Owen J., (2009). "DEVELOPING A LOW ENERGY ARCHITECTURE FOR EUROPE" -research paper. Energy Research Group, School of Architecture, University College, Ireland.

[12] Lowe, M. (1990)," ALTERNATIVE TO THE AUTOMOBILE: TRANSPORT FOR LIVABLE CITIES", World watch Paper 98.

[13] Ode, Susan. "HIGH PERFORMANCE CITIES: A GUIDE TO ENERGY-SAVING POLICIES FOR URBAN AREA", ICLEI local Governments for Sustainability.

[14] Salama, A. (1999). "DESIGNING FOR SUSTAINABLE FUTURE: REFLECTIONS ON ARCHITECTURE EDUCATION IN AFRICA AND MIDDLE EAST", Proceedings of the 2nd International Conference on Sustainability in Desert Region, SDR 99, United Arab Emirates University, Al-Ain, UAE.

[15] Salama, A. (2002). "A CRITICAL THOUGHT ON SUST AINABILITY". IAPS-Bulletin of People Environment Studies. Netherlands: Technical University of Eindhoven. 
[16] U.S. Green Building Council and Hamilton, Booz Allen, (2009)."GREEN JOBS STUDY".

[17] Moser, G., \& etal, (2003). "PEOPLE, PLACES, AND SUST AINABILITY", Hogrefe \& Huber Publications, USA

[18] Rotenberg, R., (1993). Introduction", in R. Rotenberg \& G. McDonogh (eds.) The Cultural Meaning of Urban Space, Westport, Connecticut \& London: Bergin \& Garvey, xi-xix.

[19] www.wikipedia.com, 2012

[20] Marilyn, T., (2007). "TRADITION OR INVENTION: REMEMBERING AND REVIVING MEANING OF PLACES", Icomos Australia

[21] Schulz, C., (2000). "ARCHITECTURE: PRESENCE, LANGUAGE, PLACE". Skira Editore, Milan.

[22] Valincia, B.," BUILDING THE INFRASTRUCTUREZERO
CARBON CITY", June 2008.

[23] Francis Crick \& James Watson, "DNA, the Language of Evolution", www.wikipedia.com, 2012.

[24] Froeschle, L. (1999). "ENVIRONMENTAL ASSESSMENT AND SPECIFICATION OF GREEN BUILDIND MATERIALS", the construction specifier.

[25] Spiegel, R. and Meadows, D. (1999). "GREEN BUILDIND MATERIALS: A GUIDE TO PRODUCT SELECTION AND SPECIFICATION", John Wiley\& Sons, Inc., New York.

[26] Roodman, D. M. and Lenssen, N.A. (1995). "BUILDIND REVOLUTION: HOW ECOLOGY AND HEALTH CONCERNS ARE TRANSFORMING CONSTRUCTION", World Watch paper 124, World Watch Institute, Washington, DC. 